Celebes Abdimas: Jurnal Pengabdian Kepada Masyarakat
http://journal.lldikti9.id/CER/index
Vol 2, No, 1, April 2020, pp 16-25
p-ISSN:2656-7938 dan e-ISSN: 2657-1870
DOI: https://doi.org/10.37541/celebesabdimas.v2i1.388
CEIERES ABDMAS

\title{
Pelatihan Penerapan Kurikulum 2013 Guru Sekolah Dasar Negeri Dengan Metode Pendampingan
}

\author{
Dihamri' $^{1}$, Haimah ${ }^{2}$, Abditama Srifitriani ${ }^{3}$ \\ 1 Sosiologi, Universitas Prof. Dr. Hazairin, SH Bengkulu \\ 2 Manajemen Pendidikan, Universitas Prof. Dr. Hazairin, SH Bengkulu \\ ${ }^{3}$ Lingkungan Hidup, Universitas Prof. Dr. Hazairin, SH Bengkulu \\ 1Email: dihamrimanaransyah@gmail.com
}

\section{Artikel info}

Article history:

Received: Februari-2020

Revised: Maret-2020

Accepted: April-2020

Publish: April-2020
Keywords:

Pelatihan;

Kurikulum; $S D$;

(5).
Abstract. The purpose of the training is to help elementary school teachers who have difficulty in applying the 2013 curriculum. The method used is training using the mentoring method. Assistance is carried out directly and indirectly. The teachers were accompanied directly face to face by the service team in completing assignments, indirectly the teachers were accompanied by the team via telephone, email, whatsapp and videocall. To measure the achievement of the training is a qualitative descriptive analysis. To evaluate all activities using qualitative and quantitative methods. Qualitative data collection techniques are: interviews and observations, data analysis from beginning to end. Quantitative data collection techniques are questionnaires and data analysts using a percentage formula. The results of the training are teachers increasing curriculum competency in 2013

Abstrak. Tujuan pelatihan adalah untuk membantu guru Sekolah Dasar yang mengalami kesulitan dalam penerapan kurikulum 2013. Metode yang digunakan adalah pelatihan dengan menggunakan metode pendampingan. Pendampingan dilaksanakan secara langsung dan tidak langsung. Langsung guru-guru didampingi tatap muka oleh tim pengabdian dalam menyelesaikan tugas-tugas, tidak langsung guru-guru didampingi tim melalui telepon, email, whatsapp dan videocall. Untuk mengukur ketercapaian pelatihan adalah dengan analisis deskriptif kualitatif. Untuk mengevaluasi seluruh kegiatan dengan digunakan metode kualitatif dan kuantitatif. Teknik pengumpulan data kualitatif adalah: wawancara dan observasi, analisis data dari awal sampai akhir. Teknik pengumpulan data kuantitatif adalah angket dan analis data menggunakan rumus persentase. Hasil pelatihan adalah guru-guru meningkat kompetensi kurikulum 2013.

JIn.DI Panjaitan Gang Suhanap Nomor 66 Curup Bengkulu: Email: dihamrimanaransyah@gmail.com

artikel dengan akses terbuka dibawah lisensi CC BY -4.0 
17| Celebes Abdimas: Jurnal Pengabdian Kepada Masyarakat

\section{PENDAHULUAN}

Kurikulum 2013 dirancang dengan tujuan untuk mempersiapkan insan Indonesia supaya memiliki kemampuan hidup sebagai pribadi dan warganegara yang beriman, produktif, kreatif, inovatif, dan afektif serta mampu berkontribusi pada kehidupan bermasyarakat, berbangsa, dan bernegara. Kurikulum 2013 sendiri merupakan sebuah kurikulum yang mengutamakan pada pemahaman, skill dan pendidikan karakter, dimana siswa dituntut untuk paham atas materi, aktif dalam proses berdiskusi dan presentasi serta memiliki sopan santun dan sikap disiplin yang tinggi(Arnidha \& Istiani, 2018). Dalam penerapannya dilapangan kurikulum 2013 masih banyak mengalami permasalahan. Permasalahan tersebut antara lain penyusunan rencana pelaksanaan pembelajaran (rpp), penilaian, tematik, penggunaan buku guru, buku siswa, pendekatan pembelajaran, media pembelajaran dan evaluasi. Berbagai upaya telah dilakukan pemerintah untuk mengatasi persoalan tersebut antara lain melalui pelatihan bagi guru, menyediakan buku guru, buku siswa, dan melatih para instruktur kurikulum 2013 tingkat provinsi dan nasional, namun upaya tersebut belum dapat menyelesaikan secara tuntas permasalahan yang dihadapi guru khususnya guru-guru di daerah-daerah yang memiliki banyak keterbatasan.

Mitra pengabdian adalah guru-guru SDN 65 Bukit Peninjuan II Kecamatan Sukaraja Kabupaten Seluma dan guru-guru SD Negeri sekitar SD Negeri 65. Berdasarkan wawancara dengan Ibu Susti,S. Pd (ketua mitra pengabdian dan kepala Sekolah Dasar Negeri 65 Bukit Peninjauan II Kecamatan Sukaraja), guru-guru Sekolah Dasar Negeri 65 dan SD Negeri sekitarnya masih sulit menerapkan Kurikulum 2013. Kesulitan disebabkan guru-guru masih banyak yang belum ikut pelatihan penerapan Kurikulum 2013 dan guru-guru yang telah ikut pelatihan masih banyak mengalami kesulitan untuk menerapkan kurikulum 2013. Pola pikir guru masih belum banyak berubah. Guru dalam mengajar masih lebih fokus kepada memberitahu siswa belum memahami secara optimal bahwa kurikulum 2013 menggunakan pendekatan sainstifik. Siswa seharusnya terlibat secara aktif dalam pembelajaran dengan mengamati, menanya, menalar melalui proses inquiry, eksplorasi dan elaborasi. Guru masih lebih banyak ceramah dan kegiatan berfokus pada guru. Pada umumnya guru-guru belum dapat menyusun rencana pelaksanaan pembelajaran (rpp) sesuai tuntutan kurikukum 2013. Penyusunan penilaian autentik juga masih kesulitan. Guru-guru masih sulit menyusun soal-soal dan menilai sesuai norma-norma kurikulum 2013, apalagi melaksanakan pembelajaran dan penilaian yang membawa murid memiliki kemampuan tinggi yaitu menganalisis, mengevaluasi dan mengkreasi. Guru masih banyak menggunakan penilaian dengan menggunakan pertanyaan diakhir pembelajaran dalam bentuk menjawab pertanyaan atau pilihan ganda.Tuntutan kurikulum 2013 menggambarkan peningkatan hasil belajar peserta didik, baik dalam rangka mengobservasi, menalar, mencoba, membangun jejaring, dan lain-lain, belum dapat dilakukan dalam melakukan penilaian.

Hasil penelitian sebelumnya antara lain (Krisdiana, Apriandi, \& Setiansyah, 2013) faktor yang menyebabkan kesulitan menerapkan kurikulum 2013 adalah (1) kurangnya pelatihan atau workshop tentang kurikulum 2013, (2) kurangnya sarana dan prasarana dalam pembelajaran disekolah, (3) kurangnya pemahaman terhadap kompetensi inti dan kompetensi dasar, (4) materi dan contoh soal yang disajikan dalam buku teks sulit dipahami oleh siswa, (5) guru masih menerapkan pembelajaran konvensional, sehingga kurang menggali kemampuan siswa, (6) guru kurang kreatif dalam menerapkan model dan metode pembelajaran, (7) kemampuan guru dalam pemanfaatan teknologi, informasi dan teknologi masih lemah. Selanjutnya penelitian (Reffiane, Saputra, Wakhyudin, \& Wijayanti, 2013) mengatakan, setelah mengikuti pelatihan, guru mendapatkan informasi tentang penggunaan kurikulum 2013 di tingkat SD/MI serta ketrampilan guru dalam pembuatan perangkat pengajaran kurikulum SD/MI meningkat. Penelitian (Arnidha \& Istiani, 2018) permasalahan kurikulum 2013 adalah: 1) sebagian besar guru-guru SD di Kecamatan Negerikaton belum pernah mengikuti pendampingan kurikulum 2013, 2) guru-guru SD belum semuanya memahami tentang pembuatan rencana pelaksanaan pembelajaran (RPP) sesuai kurikulum 2013, 3) guru-guru SD belum memahami pembelajaran tematik yang terintergratif, 4) guru-guru SD belum memahami tentang pembuatan soal High Order Thinking Skill (HOTS), 5) guru-guru SD merasa kesulitan dalam pengelolaan penilaian berdasarkan kurikulum 2013. Di sekolah-sekolah didaerah masih banyak guru yang belum mengikuti pelatihan 
kurikulum 2013. Kurikulum 2013 juga senantiasa mengalami revisi sesuai dengan perubahanperubahan yang terjadi khsususnya perubahan yang dipengaruhi perubahan teknologi yang semakin pesat. Penelitian yang telah dilakukan oleh Akhlis dan Dewi (Anugraheni \& Artikel, 2018) meneliti bahwa perangkat pembelajaran yang dibuat guru kurang mendukung usaha yang dilakukan guru untuk mengembangkan potensi yang ada pada diri siswa secara maksimal termasuk pembentukan karakter siswa. Listyawati (Anugraheni \& Artikel, 2018) yang meneliti bahwa guru mengalami kesulitan dalam membuat perangkat pembelajaran dalam melakukan kegiatan mengajar. Penelitian yang dilakukan Susanto (Anugraheni \& Artikel, 2018) menyebutkan bahwa guru dalam kegiatan pembelajaran belum menggunakan model pembelajaran yang bervariasi dan guru tidak melengkapi diri dengan perangkat pembelajaran yang ada sehingga kegiatan pembelajaran yang dihasilkan kurang sistematis. Penelitian yang dilakukan Stiadi (Stiadi, 2016) untuk jenjang SD perlu diberikan pelatihan teknik penilaian pada pembelajran tematik, dan membimbing guru melakukan kegiatan analisis instrumen dan revisi butir soal. Berdasarkan pendapat Stiadi tersebut maka pelatihan bagi guru untuk pelaksanaan. Penelitian Zuhera (Ilmiah, Guru, Dasar, \& Kuala, 2017) kesulitan guru dalam penerapan kurikulum 2013 penilaian sikap dan menyusun soal.

Urgensi kegiatan pelatihan adalah peningkatan kompetensi guru-guru SD Negeri 65 dalam Kurikulum 2013. khususnya penyusunan rencana pembelajaran (RPP) dan penyusunan penilaian HOTS. Manfaatnya adalah guru dapat menyusun rencana pelaksanaan pembelajaran (rpp) dan penyusunan penilaian HOTS serta dapat menerapkan dalam pembelajaran. Melalui pelatihan pendampingan diharapkan guru-guru dapat menerapkan kurikulum 2013 dalam proses pembelajaran.

FKIP Unihaz sejak tahun 2014 telah bermitra dengan Dinas Pendidikan Kabupaten Seluma khususnya dalam pembinaan kepala sekolah, guru-guru, administrasi sekolah, pembinaan karakter siswa dan beberapa rencana kegiatan lainnya sedang dalam pengkajian. Tim Pengabdian dan penelitian FKIP Unihaz pada tahun 2015 telah mulai mengerjakan beberapa kegiatan dengan Unit Pelaksana Teknis Dinas Pendidikan (UPTD) Kecamatan Sukaraja antara lain dijadikan salah satu sampel dalam uji coba peneliltian Hibah Bersaing tahun pertama (Sutardi dkk.2016-2017) dengan judul Pengembangan Model Belajar Bermutu (Better Education through Reformed Manajemen and Universal Teacher Upgrading) Yang Adaptif Untuk Meningkatkan Kinerja Guru SDN Terpencil di Provinsi Bengkulu. Tahun 2017 tim pengabdian Unihaz melaksanakan pelatihan publikasi ilmiah bagi guru dan kepala sekolah yang dibiayai DRPM. Tahun 2017 dan 2018 Ketua Pengabdian ini adalah anggota penelitian dasar yang juga dibiayai DRPM Ristekdikti. Rencana Pelatihan guru-guru di SDN 65 dan SDN adalah lanjutan kegiatan kerjasama FKIP Unihaz dengan Dinas Pendidikan kabupaten Seluma dan tahun 2018 dan 2019 fokus di desa binaan Unihaz yaitu desa Bukit Peninjuan II. Sampai sekarang kerjasama dengan guru-guru berjalan dengan sangat baik. Berdasarkan pengalaman dan keahlian tim pengabdian yang juga dibantu oleh guru-guru yang berpengalaman dan kerjasama yang sudah terjalin maka kegiatan pelatihan akan berjalan dengan baik dan lancar.

Tinjauan Pustaka Pelatihan dengan pendampingan adalah salah satu cara yang efektif agar guru keluar dari kesulitan yang dihadapi. Istilah pendampingan sering dirujuk dari bahasa Inggris mentoring dan coaching walaupun memmpunyai makna yang sedikit berbeda. Pada dasarnya, mentoring dan coching merupakan aktivitas belajar dan pengembangan yang membagi akar yang sama sekalipun masih menyisakan perdebatan yang tajam bagi para akademisi dan praktisi karena menyangkut makna dan implikasi dari masing-masing kata tersebut. Kedua kata ini digunakan ketika tingkat kinerja dan motivasi perlu diperbaiki. Dalam koteks pelatihan guru, dengan adanya pendampingan diharapkan dapat membantu dan mendorong mereka untuk menciptakan pemahaman baru terkait dengan bagaimana cara mereka mengajar, membantu mereka untuk memperoleh ide-ide baru, serta untuk memahami apa yang mereka butuhkan agar dapat meningkatkan aspek-aspek laian dari cara mereka mengajar.(Wahyuningtyas \& Shinta, 2017).

Solusi masalah atau penyelesaian kesulitan penerapan kurikulum 2013 di SD Negeri 65 Bukit Peninjauan II Kecamatan Sukaraja kabupaten Seluma, adalah penyelesaian guru dalam penyusunan rencana pelaksanaan pembelajaran (RPP) dan penyusunan penilaian sesuai 
kurikulum 2013 atau penilaian Higher Order Thinking Skill (HOTS). Solusi permasalahan yang disepakati dengan ketua mitra Kepala SD Negeri 65 Bukit Peninjauan II Kecamatan Sukaraja adalah diadakan kegiatan pelatihan penerapan kurikulum 2013 dengan metode pendampingan terstruktur atau langsung dan dengan metode pendampingan tidak langsung dengan dibantu teknologi yaitu telepon, whatsapp, email dan video call. Materi umum tentang K13 tetap akan diberikan tetapi waktunya lebih sedikit, agar guru-guru juga memahami dasar-dasar yang melatarbelakangi kurikulum 2013.

\section{Metode}

Pelatihan dilaksanakan tiga kali pertemuan yaitu tanggal 20 Agustus 2019 dan tanggal 30-31 Agustus 2019. Tempat pelatihan di SD Negeri 65 Bukit Peninjauan II Kecamatan Sukaraja kabupaten Seluma provinsi Bengkulu. Tim pengabdian berjumlah 7 orang terdiri dari 4 orang dosen FKIP Unihaz dan 1 orang instruktur nasional Kurikulum 2013 dari guru SD Negeri 01 Kota Bengkulu, 2 orang instruktur yang telah mengikuti pelatihan kurikulum 2013 tingkat provinsi dari SD Pelita Kasih Bengkulu. Peserta pelatihan berjumlah 11 orang.

Pendekatan untuk menyelesaikan kesulitan guru-guru menerapkan kurikulum 2013 adalah pelatihan dengan metode pendampingan.

Prosedur kerja pelatihan adalah: a. Persiapan. Kegiatan persiapan terdiri 8 sesi: 1) pembagian tugas tim, 2) menyusun jadwal pelatihan, 3) mempersiapkan alat-alat pelatihan, 4) mengurus surat izin pelatihan, 5) koordinasi dengan mitra, 6) mengecek kesiapan peserta, 7) penyiapan alat transportasi, 8) persiapan alat-alat dan bahan yang diperlukan dalam pelatihan. b. Pelaksanaan. Kegiatan pelaksanaan 10 sesi: 1) pembukaaan pelatihan 2) tes awal peserta pelatihan,3) Materi awal, perubahan kurikulum 2013, 4) model-model pembelajaran 5) pola tematik, buku guru dan buku siswa, 6) penyusunan rencana pembelajaran (rpp) dan penilaian penilaian kurikulum 2013, 7) guru diberi tugas, 8) pendampingan, 9) peer teaching atau praktek, 10) tes akhir. c. Penutup. Kegiatan penutup:1) pertemuan tim untuk membuat laporan, 2) membuat laporan, 3) menyebarkan informasi, 4) menyampaikan laporan, 5) mengirim artikel ilmiah ke jurnal.

Prosedur kerja pendampingan adalah pendampingan secara langsung dan tidak langsung. Pendampingan langsung adalah tatap muka selama pelatihan khususnya dalam mengerjakan tugastugas. Pendampingan tidak langsung adalah menggunakan media komunikasi internet. Peserta dapat memperoleh bimbingan melalui telepon, email, whatsaap dan video call. Peserta pelatihan diharapkan mengembangakn kemampuan IT untuk membantu pemahaman dan penerapan materi (Wahyuningtyas \& Shinta, 2017). .

Untuk mengukur ketercapaian pelatihan adalah dilaksanakan tes awal dan tes akhir kegiatan pelatihan dengan analisis deskriptif kualitatif N- Gain Score seperti dikemukakan Hake (Laksana, Chrisyarani, \& Werdiningtiyas, 2018) ) dengan rumus sebagai berikut:

$$
\begin{aligned}
& \mathbf{g}=\frac{\text { Spost-Spre }}{\text { Smak-Spre }} \\
& \text { Keterangan }:(\mathrm{g})=\text { nilai gain } \\
& \text { Spost }=\text { nilai post-test } \\
& \text { Spre }=\text { nilai pre-test } \\
& \text { Smax }=\text { nilai maksimal }
\end{aligned}
$$

Gain menunjukkan perbedaan penguasaan konsep tentang penyusunan rpp dan penilaian K13 sebelum dan setelah diberikan perlakuan. Gain skor ternomalisasi menunjukkan tingkat efektivitas perlakuan dari pada perolehan skor atau post test. Nilai (g) yang diperoleh diinterpretasikan dengan klasifikasi pada tabel 1.

Tabel 1. Interprestasi Nilai Gain Yang Dinormalisasi

\begin{tabular}{c}
\hline Nilai $(\mathrm{g})$ Interpretasi \\
\hline$(\mathrm{g})=0,7$ Tinggi \\
$0,7>(\mathrm{g})=0,3$ Sedang \\
$(\mathrm{g})<0,3$ Rendah \\
\hline
\end{tabular}


Untuk mengevaluasi seluruh kegiatan dengan digunakan metode kualitatif dan kuantitatif. Teknik pengumpulan data kualitatif adalah: wawancara dan observasi, analisis data kualitatif dari awal sampai akhir. Teknik pengumpulan data kuantitatif adalah angket dan analis data menggunakan rumus persentase.

Luaran peserta pelatihan mengumpulkan tugas penyusunan penilaian kurikulum 2013 dan rencana pelaksanaan pembelajaran (rpp).

\section{Hasil Dan Pembahasan}

Pelatihan dilaksanakan tiga kali pertemuan yaitu tanggal 20 Agustus 2019 dan tanggal 30 - 31 Agustus 2019. Waktu pelatihan disesuaikan dengan waktu yang memungkinkan semua guru dapat hadir dalam pelatihan. Tempat kegiatan pelatihan di SD Negeri 65 Bukit Peninjauan II Kecamatan Sukaraja Kabupaten Seluma. Tim pengabdian berjumlah 7 orang terdiri dari 4 orang dosen FKIP Unihaz dan 1 orang instruktur nasional Kurikulum 2013 dari guru SD Negeri 01 Kota Bengkulu, 2 orang instruktur yang telah mengikuti penataran Kurikulum 2013 tingkat provinsi (dari SD Pelita Kasih Bengkulu). Peserta pelatihan 11 orang guru Sekolah Dasar Negeri 65 dan guru-guru SD Negeri yang berdekatan dengan SD Negeri 65.

Pelaksanaan kerja pelatihan dilaksanakan sesuai yang disusun dalam rencana adalah sebagai berikut perencanaan, pelaksanaan dan penutup.

Perencanaan, persiapan pelatihan dimulai dengan pertemuan awal tim pengabdian. Agenda pertemuan membagi tugas menyusun materi, menyusun jadwal pelatihan. Kemudian tim pengabdian menyiapkan alat-alat penunjang yang akan digunakan antara lain: alat tulis, map, infokus, kamera, spanduk, stempel dan kendaraan yang akan digunakan. Selanjutnya tim pengabdian mengurus surat izin, mohon surat pengantar dari LPPM Unihaz kemudian menyampaikan surat pengantar LPPM Unihaz ke Kepala Kantor Pusat Terpadu Kabupaten Seluma, Kesbang Seluma dan Kepala Dinas Pendidikan Kabupaten Seluma. Surat Izin diperoleh dengan baik, kegiatan pelatihan disambut baik khususnya Dinas Pendidikan Kabupaten Seluma. Kemudian tim pengabdian menghubungi kesiapan peserta yang hadir dan meminta data-data berupa nama, nomor induk pegawai, pangkat dan nomor handphone (HP). Dalam persiapan tim pengabdian selalu berkoordinasi dengan ketua Mitra Kepala SD 65, peserta dan kepala UPT Dinas Pendidikan Sukaraja Kabupaten Seluma. Koordinasi antara lain melalui telepon, whatsapp dan bertemu secara langsung. Setelah persiapan selesai tim berkoordinasi dengan ketua mitra Kepala SDN 65, menjelaskan bahwa persiapan pelatihan sudah selesai. Pada tahap ini tim menjelaskan rencana realisasi pelaksanaan kegiatan pelatihan.Kegiatan pelaksanaan pelatihan dilaksanakan berdasarkan kesepakatan antara tim pengabdian, ketua mitra dan guru-guru peserta pelatihan. Ketua mitra menyiapkan ruangan, pengeras suara, daftar hadir dan konsumsi selama pelatihan.

Pelaksanaan, kegiatan pelatihan terdiri dari 10 sesi. Sesi 1 adalah acara pembukaan. Pembukaan dilaksanakan tanggal 20 Agustus 2019 di SD Negeri Bukit Peninjauan II Kecamatan Sukaraja kabupaten Seluma provinsi Bengkulu. Acara pembukaan dihadiri oleh kepala UPT Dinas Pendidikan Sukaraja, tim pengabdian, instruktur dan peserta. Acara pembukaan dipandu anggota tim pengabdian Dra. Haimah, M.Pd. Susunan acara yaitu pembukaan, sambutan ketua mitra, sambutan ketua tim pengabdian, sambutan ketua UPT Dinas Pendidikan dan sekaligus membuka acara pelatihan, terakhir doa dipimpin oleh wakil peserta pelatihan. Dalam sambutan, ketua mitra menyampaikan bahwa kegiatan pelatihan ini, sangat ditunggu dan diminati guru-guru karena sangat dibutuhkan guru-guru yang belum pernah ikut pelatihan Kurikulum 2013 dan bagi yang sudah ikut pelatihan acara ini juga sangat bermanfaat untuk menyegarkan kembali pengetahuan kurikulum 2013. Ketua mitra menyampaikan laporan dan sambutan menyampaikan terima kasih kepada tim pengabdian yang melaksanakan kegiatan ini sebagai lanjutan kerjasama atau MoU dengan SDN 65. FKIP Unihaz yang telah bekerjasama dengan guru-guru sekolah dasar negeri kecamatan Sukaraja berlangsung sekitar 4 tahun. Ketua Mitra juga berharap semua peserta dapat mengikuti kegiatan pelatihan dengan sungguh-sungguh dan mengikuti setiap tahap kegiatan pelatihan dari awal hingga akhir. Kemudian ketua Mitra juga berharap tim Pengabdian FKIP Unihaz berkenan memberikan piagam kepada peserta pelatihan sebagai bukti telah ikut pelatihaan K13 yang juga dapat digunakan untuk naik pangkat. Berikutnya sambutan ketua tim yang disampaikan langsung Drs. Dihamri, M.Si. Dalam sambutan ketua tim pengabdian menyampaikan dasar hukum kegiatan pelatihan, tujuan kegiatan, tahapan kegiatan, dan luaran atau tagihan sebagai luaran kegiatan yaitu semua peserta dapat membuat rpp yang terbaru sesuai pelatihan dan menyampaikan kepada tim 


\section{1| Celebes Abdimas: Jurnal Pengabdian Kepada Masyarakat}

pada akhir kegiatan. Ketua tim juga mengucapkan terima kasih kepada kepala UPT Dinas Pendidikan yang sudah hadir dan memohon untuk membuka secara resmi kegiatan pelatihan. Ketua tim juga mengucapkan terima kasih kepada ketua mitra dan seluruh peserta dan berharap dapat mengikuti kegiatan dari awal sampai selesai. Terakhir sambutan dari kepala UPT Dinas Pendidikan yang menyampaikan ucapan terima kasih kepada tim pengabdian Unihaz yang telah bersedia melaksanakan pengabdian kepada guru-guru SD 65, berharap kegiatan kegiatan seperti ini dapat berlanjut pada kegiatan-kegiatan lainnya dalam rangka peningkatan kualitas pendidikan khususnya guru di Kecamatan Sukaraja. Kepala UPT Dinas Pendidikan juga berpesan agar mengikuti kegiatan ini dengan sebaikbaiknya dan juga berharap mematuhi kegiatan pelatihan dengan baik serta mendukung agar kegiatan dapat berjalan dengan baik. Setelah menyampaikan sambutan kepala UPT Dinas Pendidikan membuka kegiatan secara resmi. Acara ditutup dengan doa oleh peserta pelatihan dan terakhir ramah tamah dengan menikmati makanan ringan yang sudah disiapkan oleh panitia. Acara pembukaan terlaksana dengan baik atas kerjasama tim, mitra, diknas dan peserta. Acara pembukaan yang terlaksana dengan baik, mempererat hubungan antar guru, guru dengan tim pelaksana dan instruktur. Peserta nampak lebih bersemangat karena memahami tujuan pelatihan dari laporan ketua tim pengabdian. Peserta juga bersemangat karena UPT Diknas hadir dalam pembukaan dan memberikan motivasi kepada peserta pelatihan atau guru-guru. Sesi 2 tes awal.Setelah acara pembukaan dilaksanakan tes awal.Tujuan tes awal dalah untuk mengetahui kompetensi awal peserta pelatihan dan bidang apa yang perlu mendapat perhatian lebih dalam pelatihan khususnya dari segi waktu. Tes awal diikuti 11 orang peserta pelatihan. Soal tes awal berjumlah 25 soal pilihan ganda. Hasil tes awal menunjukan pemahaman guru tetang K13 sudah cukup baik yaitu rata-rata mencapai angka 79.45, termasuk kategori cukup. Sesi 3 materi awal. Setelah kegiatan tes awal, mulai dilaksanakan kegiatan pelatihan sesi materi materi umum. Materi yang disampaikan adalah rasionalisasi kurikulum 2013 dan perubahan pola pikir. Materi meliputi: pengertian kurikulum 2013, pengembangan kurikulum 2013, dasar-dasar perubahan kurikulum 2013, antara lain permendikbud yang berkaitan dengn kurikulum 2013 dan faktor yang mempengaruhi perubahan kurikulum 2013 baik faktor internal maupun eksternal, pola pikir kurikulum 2013, elemen perubahan kurikulum 2013, struktur kurikulum 2013 dan proses yang mendukung kreativitas. Sesi 4 materi pelatihan adalah model-model pembelajaran tematik, manajemen kelas dan Saitifik. Materi meliputi: dicovery learning (teori belajar yang didefinisikan sebagai proses pembelajaran yang terjadi bila pelajar tidak disajikan dengan pelajaran dalam bentuk finalnya, tetapi diharapkan siswa mengorganisasisendiri), project based learning (metode pembelajaran yang menggunakan proyek/kegiatan sebagai media), problem based learning (Pembelajaran berbasis masalah merupakan sebuah pendekatan pembelajaran yang menyajikan masalah kontekstual sehingga merangsang peserta didik untuk belajar), manajemen kelas (mengenal murid secara individu, dan latar belakang), saintifik (pembelajaran menyentuh 3 ranah, sikap, pengetahuan dan keterampilan dengan langkah pembelajaran yaitu mengamati, menanya, menalar, mencoba dan membentuk jejaring. Sesi 5, materi pelatihan pola tematik dan analisis buku guru dan buku siswa kurikulum 2013. Materi konteks, teks, tuntutan Kurikulum 2013 pada guru dan siswa, cara menggunakan buku guru, cara menggunakan buku siswa dan revisi buku guru dan siswa, dan sumber-sumber yang dapat dipakai untuk pengembangan materi. Sesi ke 6 adalah rencana pelaksanaan pembelajaran (RPP) dan penilaian. Materi rencana pelaksanaan pembelajaran meliputi: identitas sekolah, identitas mata pelajaran, kelas/semester, alokasi waktu, tujuan pembelajaran, kompetensi dasar dan indikator, materi pembelajaran, metode pembelajaran, media pembelajaran, sumber belajar, langkah-langkah pembelajaran dan penilaian Higher Order Thinking Skill (HOTS). Sedangkan untuk penilaian HOTS meliputi strategi penyusunan soal dan penilaian. Dalam materi HOTS juga dilatih menggunakan aplikasi dan manual penilaian kurikulum 2013. Mendokumenkan nilai secara manual dengan baik, gunanya apabila orang tua bertanya tentang nilai anak mereka, guru dapat menjelaskan dengan data yang secara manual dimiliki guru. Sesi ke 7 adalah guru-guru diberi tugas untuk menyusun rencana pelaksanaan pembelajaran dan penyusunan soal berdasarkan kurikulum 2013. Sesi 8 adalah pendampingan penyusunan rencana pelaksanaan pembelajaran (rpp) dan penyusunan soal serta penilaian HOTS. Pada acara pendampingan ini peserta didampingi 4 orang, terdiri dua orang tim pengabdian dan dua orang instruktur kurikulum 2013. Pada sesi kedelapan ini diberi kesempatan menyampaikan menyampaikan tugas yang mereka buat dan kesulitan yang mereka hadapi dalam menyusun rencana pelaksanaan pembelajaran dan penyusunan soal HOTS.Tim pengabdian dan instruktur berupaya membantu menyelesaikan kesulitan yang dihadapi guru-guru menyusun rencana pelaksanaan dan menyusun soal kurikulum 2013. Kemudian guru-guru diberikan kesempatan 
menyelesaikan rencana pelaksanaan pembelajaran (RPP) dan penyusunan soal. Setelah selesai guruguru menyusun rencana pelaksanaan pembelajaran dan penyusunan soal HOTS, guru-guru mengumpulkan rencana pelaksanan pembelajaran dan yang dilengkapi dengan soal HOTS. Sesi ke 9 adalah peer teaching (guru praktek mengajar didepan teman-teman peserta) sesuai dengan rencana pelaksanaan (RPP) yang telah disusun. Setelah praktek mengajar diadakan evaluasi dengan melibatkan peserta pelatihan, tim pengabdian dan instruktur untuk memberikan masukan berupa saran-saran agar guru-guru memperbaiki kelemahan-kelemahan yang terjadi waktu praktek. Sesi ke 10 adalah adalah tes akhir. Tes akhir dilaksanakan dengan cara tertulis dan guru-guru diberikan kesempatan untuk memberikan masukan secara tertulis tentang pelaksanaan pelatihan dan manfaat serta kepuasaan dalam mengikuti pelatihan dan pendampingan kurikulum 2013. Kegiatan pelatihan dan pendampingan ini juga menggunakan pendampingan melalui media komunikasi yaitu telepon, whatsapp, email dan video call. Semua file bahan-bahan pelatihan, power point dan video dibagikan kepeserta pelatihan pelatihan melalui whatsapp pribadi ketua mitra dan grup. Peserta juga mengirimkan tugas-tugas melalui whatsapp dan email. Media komunikasi sangat bermanfaat dan membantu dalam bimbingan dan komunikasi tim pengabdian dengan ketua mitra dan peserta pelatihan. Media komunikasi yang paling banyak digunakan adalah whatshapp karena lebih mudah menggunakan dan semua peserta memiliki handphone (hp) android.

Pentutupan, penutupan pelatihan dilaksanakan pada 31 Agustus 2019 di SD Negeri 65 Bukit Penijauan II kecamatan Sukaraja. Acara penutupan dihadiri oleh tim pengabdian, instruktur dan peserta pelatihan. Acara penutupan adalah sambutan ketua mitra, sambutan tim pengabdian sekaligus penutupan acara kegiatan pelatihan dan doa. Dalam sambutan ketua Mitra ibu Susti, SPd menyampaikan terima kasih kepada tim pengabdian, instruktur, dan seluruh peserta atas terselenggaranya acara pelatihan pendampingan telah berjalan sangat baik. Ketua mitra juga menjelaskan bahwa pelatihan sangat bermanfaat bagi guru-guru SD. Kegiatan pelatihan telah meningkatkan kompetensi guru tentang kurikulum 2013, seraya berpesan agar peserta memperdalam serta mempraktekkan hasil pelatihan dan terus berkomunikasi dengan tim dan instruktur antara lain melalui whatsapp. Ketua tim pengabdian Drs. Dihamri, M.Si juga mengucapkan terimakasih dan sekaligus permintaan maaf kepada mitra, peserta, penjaga sekolah, ketua UPT Dinas Pendidikan, instruktur dan semua pihak yang telah mendukung sehingga kegiatan pelatihan kurikulum 2013 di Sekolah Dasar Negeri 65 Bukit Peninjauan II kecamatan Sukaraja berjalan dengan sangat baik. Ketua tim juga berpesan agar guru-guru yang ikut pelatihan belajar dan terapkan apa yang telah dipelajari selama pelatihan, dan membagikan ilmu yang diperoleh selama pelatihan kepada rekan-rekan guru disekolah masing-masing. Walau acara pelatihan sudah selesai tetapi komunikasi tetap dibina dan bila diperlukan tim pengabdian dan instruktur tetap bersedia membantu antara lain melalui media grup whatsapp K13 yang sudah terbentuk. Kemudian ketua tim pengabdian menutup secara resmi kegiatan pelatihan penerapan kurikukulum 2013 bagi guru-guru SD Negeri kecamatan Sukaraja kabupaten Seluma. Doa penutup yang disampaikan salah satu peserta pelatihan Bpk Sehwani, SPd, setelah doa diakhiri dengan foto bersama dan pemberian sertifikat pelatihan. Sertifikat pelatihan sangat dibutuhkan guru-guru sebagai bukti ikut pelatihan dan bahan laporan kepada kepala sekolah yang mengutus dan sekaligus bermanfaat untuk kenaikan pangkat.

Pelatihan dan pendampingan diikuti guru-guru dengan penuh antusias. Indikator semangat antara lain dilihat dari kehadiran, keaktifan dalam diskusi, mengerjakan tugas dan mengumpulkan tugas dan praktek mengajar serta komunikasi melalui media komunikasi yang disediakan antara lain whatsapp. Persentase kehadiran 11 orang peserta dalam tiga kali pertemuan dari pukul $08.00-17.00$ WIB sejumlah $100 \%$, hanya ada dua orang terlambat dua jam karena ada tugas dinas yang perlu diselesaikan. Selama pelatihan peserta aktif memperhatikan dan bertanya tentang kesulitankesulitanyang mereka hadapi dalam menerapkan kurikulum 2013, menyimpan bahan-bahan pelatihan antara lain power point, video di whatsapp, flashdisk dan lap top. Tugas penyusunan rencana pelaksanaan pembelajaran (RPP) yang dilengkapi dengan penilaian HOTS dikerjakan dengan baik, 11 peserta atau $100 \%$ peserta berhasil mengumpulkan rencana pelaksanaan pembelajaran (RPP). Rencana pelaksanaan yang dikumpulkan juga dikoreksi oleh tim pengbadian dan instruktur, kemudian hasilnya disampaikan kepada peserta, melalui ketua mitra. Hal ini sesuai dengan yang dikemukakan (Reffiane et al., 2013) setelah mengikuti kegiatan pelatihan, peserta pelatihan dapat memahami rasional dan perubahan kurikulum, SKL, KD dan KI, Indikator serta strategi implementasi kurikulum 2013, sehingga memudahkan guru dalam implementasi kurikulum 2013. Setelah diadakan pelatihan guru banyak mendapat pengetahuan mengenai kurikulum 2013 (Laksana et al., 2018) 
Pelaksanaan pelatihan dan pendampingan dilakukan dengan joyfull learning seperti yang dikemukakan Corbei (Maryani \& Septiani, 2019). Dalam mengikuti pelatihan dan pendampingan peserta tidak mengalami kesulitan, guru-guru terus bersemangat, karena tim mendampingi mereka seperti teman dan mendengarkan dengan seksama sesama apa yang mereka keluhkan. Tim berupaya membuat guru senantiasa senang dan bersemangat dalam mengikuti pelatihan. Semangat sangat menentukan keberhasilan penerapan kurikulum seperti dikemukakan Krisandi dan Rusamawan (Arnidha \& Istiani, 2018). Kurikulum yang sederhana pun, apabila gurunya memiliki kemampuan, semangat, dan dedikasi yang tinggi, hasilnya akan lebih baik dari desain kurikulum yang hebat. Kegiatan pelatihan diselingi dengan latihan lagu-lagu nasional dan daerah serta praktek tepuk dan salam penguatan pendidikan karakter (PPK) dan disediakan konsumsi dan ruangan cukup repsentatif. Semua meja diberi taplak yang beraneka warna, sehingga tampak serasi. Kegiatan pelaksanaan juga terlaksana dengan baik kerena dipersiapkan dengan baik. Menurut Rusman (Arnidha \& Istiani, 2018) untuk menerapkan atau mengimplementasikan kurikulum diperlukan kesiapan pelaksana. Selanjutnya Katuuk (Arnidha \& Istiani, 2018) mengemukakan bahwa ada beberapa aspek manajemen sebagai strategi untuk memperkuat pelaksanaannya. Aspek yang dimaksud mencakup hal-hal seperti perencanaan implementasi, sumber daya utama dan pendukung, pro-pelaksanaan pembelajaran di sekolah, serta kegiatan monitoring dan evaluasi.Tim Pengbadian juga telah berupaya dengan sebaik-baiknya menyiapkan dan memonitoring kegiatan ini, maka terlihat hasilnya kegiatan berjalan baik dan lancar serta mendapat respon sangat positif dari ketua mitra dan peserta pelatihan. Menurut Rahmawati (Masalah \& Revisi, 2018) guru juga harus mampu memaksimalkan kemampuan profesionalnya untuk menjawab tantangan-tantangan di dalam kurikulum 2013.

Tabel 1. Nilai Kompetensi Kurikulum 2013

\begin{tabular}{cccccc}
\hline No & Nama & Pretes & Postes & Nilai Gain Scor & Kategori \\
\hline 1 & SSI & 80 & 95 & 0,75 & Tinggi \\
2 & PTO & 80 & 94 & 0,70 & Tinggi \\
3 & SMI & 80 & 90 & 0,50 & Sedang \\
4 & SWI & 80 & 90 & 0,50 & Sedang \\
5 & DWI & 79 & 90 & 0,52 & Sedang \\
6 & HPI & 81 & 95 & 0,73 & Tinggi \\
7 & SPO & 80 & 87 & 0,35 & Sedang \\
8 & ELI & 73 & 80 & 0,26 & Rendah \\
9 & LSA & 84 & 96 & 0,75 & Tinggi \\
10 & SLI & 74 & 80 & 0,23 & Rendah \\
11 & IDA & 83 & 96 & 0,76 & Tinggi \\
& & 874 & 993 & & \\
& Rata-rata & 79,45 & 90,27 & & \\
\hline
\end{tabular}

Dampak kegiatan adalah guru-guru meningkat kompetensi tentang Kurikulum 2013. Komptensi guru-guru tentang Kurikulum 2013 meningkat. Sebelum pelatihan, tingkat pengetahuan guru-guru peserta pelatihan mendapatkan nilai rata-rata 79,45 dan sesudah pelatihan tingkat kompetensi guru-guru meningkat menjadi 90,27 ( $45.45 \%$ kategori Tinggi, $36.36 \%$ kategori sedang dan $18.18 \%$ kategori rendah). Sebelum pelatihan guru-guru sulit dalam penyusunan rencana pelaksanaan pembelajaran dan penyusunan dan penilaian sesuai kurikulum 2013. Dalam penyusunan rpp kesulitan terutama penyusunan KD dan Indikator, setelah pelatihan dilihat dari rencana pelaksanaan yang yang dikumpulkan guru-guru sudah dapat menyusun KD dan indikator. Demikian juga dengan penilaian sebelumnya guru-guru belum memahami strategi penyusunan soal dan penilaian HOTS. Sebelumnya mereka juga belum tahu istilah penilaian HOTS. Sebelumnya juga mereka belum mahami secara jelas taksonomi Bloom yang direvisi Anderson, setelah pelatihan mereka memahami dan dapat menyusun KD KI dan indikator serta penilaian yang tertera dalam rencana pelaksanaan pembelajaran (rpp) dan pelaksanaan praktek mengajar. Setelah pelatihan guru-guru dapat memahami menyusun soal penilaian HOTS. Setelah pelatihan terjadi peningkatan pemahaman guru tentang soal HOTS dan LOTS (Rusilowati, Isnaeni, \& Winarsih, 2019). Demikian pula tentang kepuasan dalam mengikuti pelatihan dengan kejelasan penyampaian materi, ketuntasan materi dan kenyamanan mengikuti pelatihan, hasilnya adalah : $18.18 \%$ menyatakan cukup puas, $18.18 \%$ menyatakan puas, dan $72.72 \%$ menyatakan 
menyatakan sangat puas. Guru SD Negeri semangat 65 semangat mengikuti pelatihan hal ini dilihat dari kehadiran peserta selama pelatihan. Guru-guru menyadari manfaat pelatihan sangat menambah pengetahuan mereka. Guru merasakan manfaat dari kegiatan pelatihan yang dilaksanakan karena dapat menjadi wawasan keilmuan baru dalam pengembangan kegiatan pembelajaran di sekolah (Riyadi, 2019). Kegiatan pelatihan pendampinangan menambah pengetahuan guru-guru (Riyadi, 2019). Peserta didik SD Negeri 65 dan guru-guru SD Negeri lainnya sudah rutin melakukan salam dan tepuk penguatan pendidikan karakter (PPK), yang sebelumnya guru-guru dan murid belum tahu. Tim mengadakan observasi ke anak-anak SD Negeri 65 semua anak-anak yang sebelumnya belum tahu salam dan tepuk PPK, setelah pelatihan anak SD Negeri 65 dapat melakukan salam dan tepuk PPK. Dampak lainnya dilihat dari pesan ketua mitra pada acara penutupan adalah meminta supaya kegiatan pelatihan dilakukan lagi untuk khususnya untuk guru-guru yang belum ikut pelatihan bahkan diharapkan pelatihan diperluas kepada sekolah-sekolah lainnya. Demikian juga masukan peserta $100 \%$ peserta menyatakan agar pelatihan dilakukan juga untuk guru-guru yang lainnya.

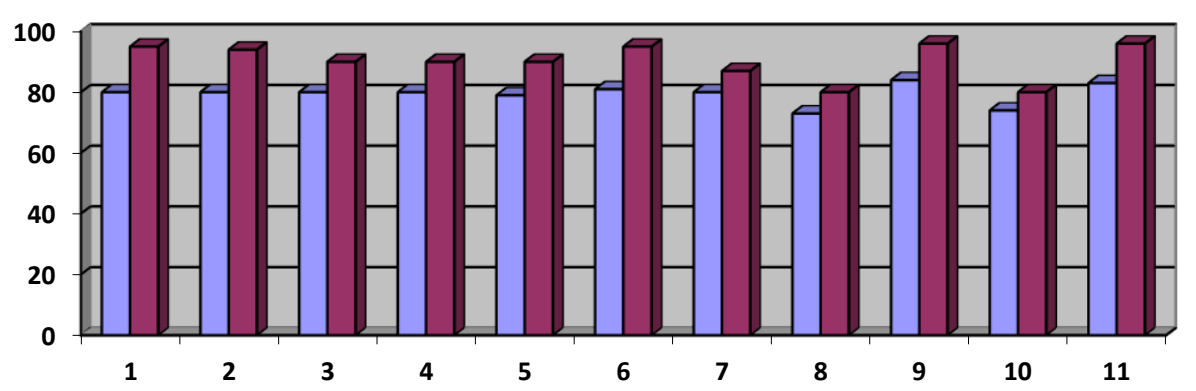

Grafik 1. Peningkatan Keterampilan Hasil Pelatihan

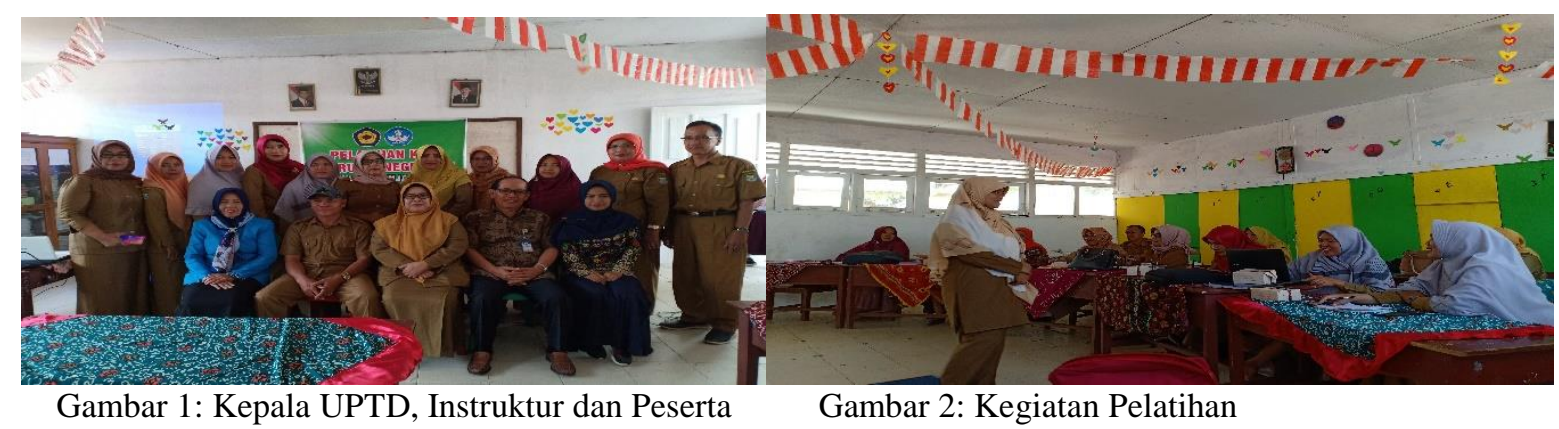

\section{Simpulan Dan Saran}

Pelatihan dengan metode pendampingan penerapan Kurikulum 2013 bagi guru-guru SD Negeri 65 Bukit Peninjauan II kecamatan Sukaraja kabupaten Seluma, telah berjalan dengan sangat baik dan lancar, sesuai dengan yang direncanakan. Kompetensi guru-guru tentang kurikulum 2013 meningkat, khususnya penyusunan rencana pelaksanaan pembelajaran (rpp) dan penilaian. Program pelatihan sangat bermanfaat bagi guru-guru karena dapat diterapkan langsung dalam pembelajaran di sekolah. Respon guru-guru mengikuti pelatihan sangat baik, pada umumnya menyatakan puas.

Saran untuk pelatihan dan pendampingan berikutnya adalah guru-guru perlu lebih banyak mendapat waktu pendampingan khususnya pendampingan penyusunan rencana pelaksanaan pembelajaran (rpp), pembuatan indikator penyusunan soal dan penilaian HOTS serta pendampingan menggunakan komputer atau teknologi informasi (TI). Pelatihan perlu dikembangkan kepada guru-guru SD lain khususnya kecamatan Sukaraja di kabupaten Seluma.

\section{Daftar Rujukan}

Anugraheni, I., \& Artikel, I. (2018). Indri Anugraheni ?], 8(2). 
25| Celebes Abdimas: Jurnal Pengabdian Kepada Masyarakat

Arnidha, Y., \& Istiani, A. (2018). Pendampingan Implementasi Kurikulum 2013 Bagi Guru Sekolah Dasar di Kecamatam Negerikaton Kabupaten Pesawaran Propinsi Lampung, 2(1), 1621.

Ilmiah, J., Guru, P., Dasar, S., \& Kuala, U. S. (2017). KENDALA GURU DALAM MEMBERIKAN PENILAIAN TERHADAP SIKAP SISWA DALAM PROSESPEMBELAJARAN BERDASARKAN KURIKULUM 2013 DI SD NEGERI 14 BANDA ACEH Yuni Zuhera, Sy. Habibah, Mislinawati, 2, 73-87.

Krisdiana, I., Apriandi, D., \& Setiansyah, R. K. (2013). DAN PESERTA DIDIK SEKOLAH MENENGAH PERTAMA DALAM IMPLEMENTASI KURIKULUM 2013 PADA MATA PELAJARAN MATEMATIKA ( Studi Kasus Eks-Karesidenan Madiun ), (7).

Laksana, J. W., Chrisyarani, D. D., \& Werdiningtiyas, R. K. (2018). Pelatihan Penyusunan Perangkat Pembelajaran K13 Di SDN Sudimoro 2 Kecamatan Bululawang Kabupaten MALANG, 7(1), 55-61.

Maryani, I., \& Septiani, P. D. (2019). Pelatihan dan pendampingan pengelolaan kelas berbasis gaya belajar bagi guru PAUD dan TK di Desa Muntuk, Dlingo , Bantul , Yogyakarta, 3(1), 103110.

Masalah, I., \& Revisi, K. (2018). Indonesian Journal of Primary Education, 2(1), 114-123.

Reffiane, F., Saputra, H. J., Wakhyudin, H., \& Wijayanti, A. (2013). PELATIHAN IMPLEMENTASI KURIKULUM 2013 BAGI GURU SD.

Riyadi, U. S. (2019). Higher Order Thinking Skills, 3(2), 14-20.

Rusilowati, A., Isnaeni, W., \& Winarsih, R. (2019). Peningkatan Kemampuan Guru SD di Kecamatan Gajah Mungkur dalam Menyusun Soal HOTS setelah Mengikuti Pelatihan, 382.

Wahyuningtyas, D. T., \& Shinta, R. N. (2017). PELATIHAN MEDIA PEMBELAJARAN MATEMATIKA BERDASARKAN KURIKULUM 2013 BAGI GURU SEKOLAH DASAR DI GUGUS 9 KECAMATAN SUKUN MALANG, 8-11. 